\title{
Rhodium-catalyzed reductive carbonylation of aryl iodides to arylaldehydes with syngas
}

\author{
Zhenghui Liu ${ }^{*}$, Peng Wang ${ }^{2,3}$, Zhenzhong Yan ${ }^{1}$, Suqing Chen ${ }^{1}$, Dongkun $\mathrm{Yu}^{4}$, \\ Xinhui Zhao ${ }^{4}$ and Tiancheng Mu*4
}

\section{Full Research Paper}

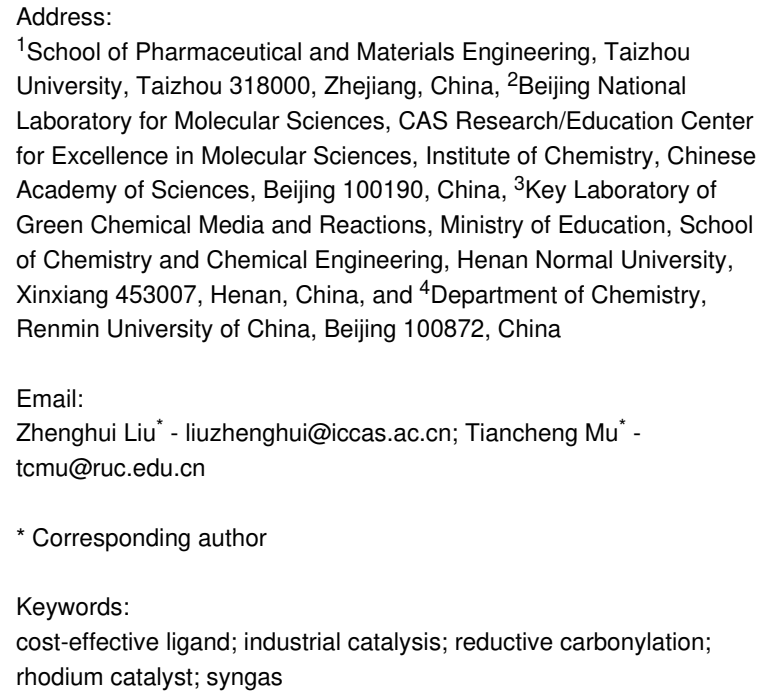

${ }^{1}$ School of Pharmaceutical and Materials Engineering, Taizhou University, Taizhou 318000, Zhejiang, China, ${ }^{2}$ Beijing National Laboratory for Molecular Sciences, CAS Research/Education Center for Excellence in Molecular Sciences, Institute of Chemistry, Chinese Academy of Sciences, Beijing 100190, China, ${ }^{3}$ Key Laboratory of Green Chemical Media and Reactions, Ministry of Education, School of Chemistry and Chemical Engineering, Henan Normal University, Xinxiang 453007, Henan, China, and ${ }^{4}$ Department of Chemistry, Renmin University of China, Beijing 100872, China

Email:

Zhenghui Liu* - liuzhenghui@iccas.ac.cn; Tiancheng Mu* -

tcmu@ruc.edu.cn

* Corresponding author

\section{Keywords:}

cost-effective ligand; industrial catalysis; reductive carbonylation; rhodium catalyst; syngas

Beilstein J. Org. Chem. 2020, 16, 645-656. doi:10.3762/bjoc. 16.61

Received: 29 January 2020

Accepted: 28 March 2020

Published: 08 April 2020

Associate Editor: K. Grela

(c) 2020 Liu et al.; licensee Beilstein-Institut. License and terms: see end of document.

\begin{abstract}
The reductive carbonylation of aryl iodides to aryl aldehydes possesses broad application prospects. We present an efficient and facile Rh-based catalytic system composed of the commercially available $\mathrm{Rh}$ salt $\mathrm{RhCl}_{3} \cdot 3 \mathrm{H}_{2} \mathrm{O}, \mathrm{PPh}_{3}$ as phosphine ligand, and $\mathrm{Et}_{3} \mathrm{~N}$ as the base, for the synthesis of arylaldehydes via the reductive carbonylation of aryl iodides with $\mathrm{CO}$ and $\mathrm{H}_{2}$ under relatively mild conditions with a broad substrate range affording the products in good to excellent yields. Systematic investigations were carried out to study the experimental parameters. We explored the optimal ratio of $\mathrm{Rh}$ salt and $\mathrm{PPh}_{3}$ ligand, substrate scope, carbonyl source and hydrogen source, and the reaction mechanism. Particularly, a scaled-up experiment indicated that the catalytic method could find valuable applications in industrial productions. The low gas pressure, cheap ligand and low metal dosage could significantly improve the practicability in both chemical researches and industrial applications.
\end{abstract}

\section{Introduction}

The exploration of environmentally friendly and highly effective synthetic methods has been a significant goal of research [1-5]. In this aspect, effective catalytic systems and organometallic chemistry are suitable technologies to accomplish these goals. Carbonylation processes are important transformations in the refinement and reprocessing of readily available industrial raw materials into more functionalized products. These processes generally utilize carbon monoxide $(\mathrm{CO})$, currently the 
most important $\mathrm{C} 1$ building block used in numerous industrial carbonylation processes [6-8] and widely applied in industrial productions [9-12]. Carbonylations are one of the industrial core technologies for transforming various bulk chemicals into useful products that are used in our daily life. Carbonylation reactions, together with polymerizations and oxidations, constitute the largest industrial applications in the field of homogeneous catalysis, and substantial value-added bulk and fine chemicals are available through this technology [13]. In spite of the existing plentiful progress in this conversion, the exploitation of advanced and more effective catalytic systems to the activity and to widen the range of substrates is crucial for new practical applications.

Syngas is a mixture of $\mathrm{CO}$ and $\mathrm{H}_{2}$, which is cheap, abundant and widely used in chemical industry productions [14-16]. In spite of its comprehensive utilization in industry, reactions involving $\mathrm{CO}$ are relatively seldom employed in fine chemicals syntheses. This could be due to the general difficulty of using gases as raw materials and the requirement of high-pressure equipment. In addition, relatively little attention has been paid to carbonylation chemistry using $\mathrm{CO}$ in academic research. Also, $\mathrm{H}_{2}$ as representative clean energy source is far more environmentally friendly than other frequently used hydrogen sources like hydrosilanes [17], tributyltin hydride $\left(\mathrm{Bu}_{3} \mathrm{SnH}\right)$ (often used in natural product syntheses) [18-20] and hydroboranes [21-23], since the only byproduct is water. The production, storage and use of $\mathrm{H}_{2}$ received much attention and plentiful achievements promoted the application of $\mathrm{H}_{2}$ into more and more chemistry researches and industrial productions [2427].

Aromatic aldehydes are highly valuable organic compounds that are widely employed as indispensable building blocks in numerous areas of chemistry, especially for the preparation of biologically active molecules or their intermediates $[28,29]$. Generally, aromatic aldehydes are synthesized by Reimer-Tiemann, Gattermann-Koch, Vielsmeier-Haag, or Duff reactions and so forth. Unfortunately, these reactions usually use auxiliary reagents and thus generate large amounts of industrial waste and other side products. Particularly, the reductive carbonylation of aryl iodides to produce arylaldehydes with $\mathrm{CO}$ and $\mathrm{H}_{2}$ was seldom reported. Some homogeneous and heterogeneous catalytic systems based on palladium species using $\mathrm{CO}$ and $\mathrm{H}_{2}$ to complete the reductive carbonylation of aryl halogens to arylaldehydes have been developed. The homogeneous systems included $\mathrm{Pd}(\mathrm{OAc})_{2}$ with propyl di-tertbutylphosphinite ligand [30], $\mathrm{Pd}(\mathrm{acac})_{2}$ with dppm ligand [31] $\mathrm{Pd}(\mathrm{OAc})_{2}$ with CataCXium A ligand [32], and all of the three systems employed TMEDA as the base and toluene as the solvent. The heterogeneous systems contained: $\mathrm{PdO} / \mathrm{Co}_{3} \mathrm{O}_{4}$ with
$\mathrm{K}_{2} \mathrm{CO}_{3}$ [33], MCM-41-S-PdCl 2 [34], and MCM-41-2P-PdCl 2 [35]. However, the aforementioned systems often suffer from high toxicity of solvents, high pressure of gases or high reaction temperatures, which make these protocols inapplicable for large scale applications. Actually, in 2004, Eliseev et al. reported a catalytic system based on $\mathrm{RhCl}(\mathrm{CO})\left(\mathrm{PPh}_{3}\right)_{2}$ to achieve the conversion of iodobenzene to benzaldehyde in toluene using $\mathrm{CO}$ and $\mathrm{H}_{2}$ [36]. We sought for a commercially available $\mathrm{Rh}$ salt for this conversion at lower cost and higher potential for practical application.

In this work, we established a catalytic system composed of $\mathrm{RhCl}_{3} \cdot 3 \mathrm{H}_{2} \mathrm{O}$ and $\mathrm{PPh}_{3}$, which allows the reductive carbonylation of aryl iodides using $\mathrm{CO}$ and $\mathrm{H}_{2}$ in the presence of $\mathrm{Et}_{3} \mathrm{~N}$ as the base at $90{ }^{\circ} \mathrm{C}$. In addition, the reported catalytic system demonstrates high catalytic activity affording the arylaldehydes in good to excellent yields, displays high functional-group tolerance, and broad substrate scope. In particular, the catalytic system could be applied in a scaled-up experiment and thus has potential for applications in industrial productions. The reaction mechanism study revealed that $\mathrm{RhCl}_{3} \cdot 3 \mathrm{H}_{2} \mathrm{O}$ reacts with $\mathrm{PPh}_{3}$ to form $\mathrm{RhCl}\left(\mathrm{PPh}_{3}\right)_{3}$, which is able to activate $\mathrm{C}-\mathrm{I}$ bonds in aryl iodides realizing the insertion of $\mathrm{CO}$ and hydrogenolysis with $\mathrm{H}_{2}$. The final trapping of $\mathrm{HI}$ by the base $\mathrm{Et}_{3} \mathrm{~N}$ regenerates the catalyst to complete the reaction cycle. As far as we know, this is the first time that commercially available Rh salts with $\mathrm{PPh}_{3}$ as the ligand were utilized to complete the conversion of aryl iodides into arylaldehydes using $\mathrm{CO}$ and $\mathrm{H}_{2}$ with systematic researches. Considering the efficiency and generality, this catalytic system is expected to powerfully influence both laboratory research and chemical industry by offering a practical synthetic tool for the conversion of aryl iodides to arylaldehydes.

\section{Results and Discussion Effects of Rh species}

Rhodium salts coordinated with proper ligands have been reported to be able to realize the activation of $\mathrm{CO}$ and $\mathrm{H}_{2}$ and thus might achieve the reductive carbonylation of aryl iodides to afford aromatic aldehydes [37-40]. Rh salts generally play vital roles in the catalytic results. Therefore, we tested 20 different $\mathrm{Rh}$ salts and the results are summarized in Table 1. The initial reaction conditions were set as $\mathrm{PhI}(1 \mathrm{mmol}), \mathrm{Rh}$ species (2.5 mol \%), $\mathrm{PPh}_{3}(10 \mathrm{~mol} \%), \mathrm{Et}_{3} \mathrm{~N}$ (1.2 mmol), DMA (2 mL), $\mathrm{CO} / \mathrm{H}_{2}$ (5 bar:5 bar), $90{ }^{\circ} \mathrm{C}$ and $12 \mathrm{~h}$. As can be seen from Table 1, most of the Rh salts gave unsatisfactory results with yields of benzaldehyde below 50\%. However, three Rh salts provided yields over $50 \%$, namely $\left[\mathrm{RhCl}(\mathrm{CO})_{2}\right]_{2}(64 \%)$, $\mathrm{RhCl}_{3} \cdot 3 \mathrm{H}_{2} \mathrm{O}$ (97\%) and $\mathrm{RhI}_{3}$ (89\%) (Table 1, entries 1, 18 and 20). Interestingly, $\mathrm{RhCl}_{3} \cdot 3 \mathrm{H}_{2} \mathrm{O}$ and $\mathrm{RhI}_{3}$ performed well, whereas $\mathrm{RhCl}_{3}$ and $\mathrm{RhBr}_{2} \cdot 2 \mathrm{H}_{2} \mathrm{O}$ afforded the product in very 
Table 1: Rhodium-catalyzed reductive carbonylation of iodobenzene with $\mathrm{CO}$ and $\mathrm{H}_{2}$ to afford benzaldehyde: effects of the $\mathrm{Rh}$ species ${ }^{\mathrm{a}}$.

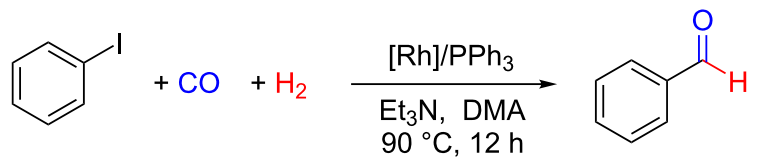

\begin{tabular}{|c|c|c|c|}
\hline Entry & Rh species & Conversion [\%] $]^{b}$ & Yield $[\%]^{b}$ \\
\hline 1 & {$\left[\mathrm{RhCl}(\mathrm{CO})_{2}\right]_{2}$} & 89 & 64 \\
\hline 2 & $\mathrm{RhCl}(\mathrm{CO})\left(\mathrm{PPh}_{3}\right)_{2}$ & 37 & 31 \\
\hline 3 & $\operatorname{Rh}(\operatorname{acac})(\mathrm{CO})_{2}$ & 21 & 15 \\
\hline 4 & {$[\mathrm{RhCl}(\mathrm{COD})]_{2}$} & 16 & 14 \\
\hline 5 & $\mathrm{Rh}(\mathrm{MeCN})_{2}(\mathrm{COD}) \mathrm{BF}_{4}$ & 15 & 12 \\
\hline 6 & $\mathrm{Rh}(\mathrm{COD}) \mathrm{BF}_{4}$ & 27 & 21 \\
\hline 7 & $\mathrm{Rh}(\mathrm{COD})_{2} \mathrm{OTf}$ & 21 & 18 \\
\hline 8 & {$[\mathrm{Rh}(\mathrm{OMe})(\mathrm{COD})]_{2}$} & 23 & 19 \\
\hline 9 & $\mathrm{Rh}(\mathrm{OAc})_{2}$ & 71 & 33 \\
\hline 10 & {$\left[\mathrm{Rh}\left(\mathrm{CF}_{3} \mathrm{COO}\right)\right]_{2}$} & 43 & 12 \\
\hline 11 & {$\left[\mathrm{Rh}\left(\mathrm{CH}_{3}\left(\mathrm{CH}_{2}\right)_{6} \mathrm{CO}_{2}\right)_{2}\right]_{2}$} & 29 & 22 \\
\hline 12 & $\mathrm{Rh}(\text { ethylene })_{2}(\mathrm{acac})$ & 48 & 42 \\
\hline 13 & {$\left[\mathrm{Rh}(\text { ethylene })_{2} \mathrm{Cl}\right]_{2}$} & 42 & 36 \\
\hline 14 & $\mathrm{Rh}$ (norbornadiene) ${ }_{2} \mathrm{BF}_{4}$ & 25 & 10 \\
\hline 15 & {$\left[\mathrm{Cp}^{*} \mathrm{RhCl}_{2}\right]_{2}$} & 51 & 46 \\
\hline 16 & $\mathrm{Rh} / \mathrm{C}$ & 38 & 21 \\
\hline 17 & $\mathrm{RhCl}_{3}$ & 22 & 18 \\
\hline 18 & $\mathrm{RhCl}_{3} \cdot 3 \mathrm{H}_{2} \mathrm{O}$ & 100 & 97 \\
\hline 19 & $\mathrm{RhBr}_{2} \cdot 2 \mathrm{H}_{2} \mathrm{O}$ & 31 & 28 \\
\hline 20 & $\mathrm{RhI}_{3}$ & 92 & 89 \\
\hline
\end{tabular}

aStandard conditions: Phl (1 mmol), Rh species (2.5 mol \%), $\mathrm{PPh}_{3}(10 \mathrm{~mol} \%), \mathrm{Et}_{3} \mathrm{~N}(1.2 \mathrm{mmol}), \mathrm{DMA}(2 \mathrm{~mL}), \mathrm{CO} / \mathrm{H}_{2}(5 \mathrm{bar}: 5 \mathrm{bar}), 90{ }^{\circ} \mathrm{C}, 12 \mathrm{~h}$. betermined by GC using dodecane as an internal standard.

low yield (Table 1, entries 17-20). This strongly implied that not only the valence state of $\mathrm{Rh}$ and the species of anions were crucial for the conversion (even if all with halogen anions), but also structural differences (e.g., crystal water, $\mathrm{RhCl}_{3}$ vs $\mathrm{RhCl}_{3} \cdot 3 \mathrm{H}_{2} \mathrm{O}$ ) of analogous $\mathrm{Rh}$ salts played an important role in the catalytic synthesis of benzaldehyde. Among all tested rhodium salts, $\mathrm{RhCl}_{3} \cdot 3 \mathrm{H}_{2} \mathrm{O}$ afforded benzaldehyde in the highest yield and was chosen as the most suitable $\mathrm{Rh}$ salt for the conversion. In addition, in spite of low yields, Rh species with valence states of $0,+1,+2$ or +3 all promoted the reaction at least to some extent. It is worth noting that as a good leaving group, $\mathrm{I}^{-}$tends to leave in an alkaline environment, and dehalogenation and direct coupling products (namely, benzene and biphenyl) were detected as the main byproducts by GC-MS. This observation also explains why the conversions were always higher than the yields.

\section{Effects of ligands}

Ligands play a decisive role in adjusting the catalytic ability of metal cations [12,13,41-51]. Different ligands coordinating with the same metal cations could make a difference between full conversion with nearly quantitative yields and no reactions. To obtain the optimized conditions, 13 kinds of ligands were tested and their structures are included in Table 2. In accordance with the expectations, only $\mathrm{PPh}_{3}$ was effective and afforded benzaldehyde in $97 \%$ yield, whereas the majority of the other ligands did not afford any product (Table 2). Therefore, $\mathrm{PPh}_{3}$ was selected as the proper ligand employed in the subsequent reactions.

\section{Effects of bases}

As explored in the mechanism study, the acid $\mathrm{HI}$ is produced during the reaction process, since $\mathrm{H}^{+}$and $\mathrm{I}^{-}$were generated from the reaction system. In order to make the reaction proceed continuously, HI produced needs to be removed effectively and in time. Five different bases were examined to assess their ability to bind HI. All of them were found suitable for the reaction and provided benzaldehyde with yields higher than $70 \%$, except for TMEDA (53\%, Figure 1a). The best results were obtained with $\mathrm{Et}_{3} \mathrm{~N}$, which was selected as the most appropriate base.

The optimized base concentration was explored next and the results are shown in Figure 1b. Since the base held the post of 
Table 2: Rhodium-catalyzed reductive carbonylation of iodobenzene with $\mathrm{CO}$ and $\mathrm{H}_{2}$ to afford benzaldehyde: effects of the ligands ${ }^{\mathrm{a}}$.

$$
+\mathrm{CO}+\mathrm{H}_{2} \frac{\begin{array}{l}
\mathrm{RhCl}_{3} \cdot 3 \mathrm{H}_{2} \mathrm{O} / \text { /igand } \\
90^{\circ} \mathrm{N}, \mathrm{DMA}, 12 \mathrm{~h}
\end{array}}{\mathrm{I}}
$$

\begin{tabular}{llll}
\hline Entry & Ligand & Conversion $[\%]^{\mathrm{b}}$ & Yield [\%] \\
\hline 1 & $\mathrm{PP}_{3}$ & 8 & 0 \\
2 & triphos & 5 & 0 \\
3 & dpp-BINAP & 12 & 0 \\
4 & dpp-OPh & 7 & 3 \\
5 & dppb & 6 & 0 \\
6 & dppe & 11 & 0 \\
7 & $\mathrm{P}(\mathrm{PhF})_{3}$ & 16 & 0 \\
8 & $\mathrm{P}(4-\mathrm{FPh})_{3}$ & 13 & 0 \\
9 & $\mathrm{Cydpp}$ & 8 & 2 \\
10 & $\mathrm{Bipy}$ & 9 & 4 \\
11 & $\mathrm{DBU}$ & 3 & 0 \\
12 & $\mathrm{Im}$ & 2 & 0 \\
13 & $\mathrm{PPh}$ & 100 & 97 \\
\hline
\end{tabular}<smiles>c1ccc(P(CCP(CCP(c2ccccc2)c2ccccc2)CCP(c2ccccc2)c2ccccc2)c2ccccc2)cc1</smiles>

$\mathrm{PP}_{3}$<smiles>c1ccc(P(c2ccccc2)c2ccccc2P(c2ccccc2)c2ccccc2)cc1</smiles>

dppb<smiles>c1ccc(P(c2ccccc2)C2CCCCC2)cc1</smiles>

Cydpp<smiles>CC(CP(c1ccccc1)c1ccccc1)(CP(c1ccccc1)c1ccccc1)CP(c1ccccc1)c1ccccc1</smiles>

triphos<smiles>c1ccc(P(CCP(c2ccccc2)c2ccccc2)c2ccccc2)cc1</smiles>

dppe<smiles>Pc1ccccc1-c1ccc2ccccc2c1-c1c(P)ccc2ccccc12</smiles>

dpp-BINAP<smiles>Fc1c(F)c(F)c(P(c2c(F)c(F)c(F)c(F)c2F)c2c(F)c(F)c(F)c(F)c2F)c(F)c1F</smiles>

$\mathrm{P}\left(\mathrm{PhF}_{5}\right)_{3}$<smiles>c1ccc(P(c2ccccc2)c2ccccc2Oc2ccccc2P(c2ccccc2)c2ccccc2)cc1</smiles>

dpp-OPh<smiles>Fc1ccc(P(c2ccc(F)cc2)c2ccc(F)cc2)cc1</smiles>

$\mathrm{P}(4-\mathrm{FPh})_{3}$<smiles>c1ccc(P(c2ccccc2)c2ccccc2)cc1</smiles>

aStandard conditions: $\mathrm{Phl}(1 \mathrm{mmol}), \mathrm{RhCl}_{3} \cdot 3 \mathrm{H}_{2} \mathrm{O}(2.5 \mathrm{~mol} \%)$, ligand (10 mol \%), $\mathrm{Et}_{3} \mathrm{~N}(1.2 \mathrm{mmol}), \mathrm{DMA}(2 \mathrm{~mL}), \mathrm{CO} / \mathrm{H}_{2}(5 \mathrm{bar}: 5 \mathrm{bar}), 90{ }^{\circ} \mathrm{C}, 12 \mathrm{~h}$. betermined by GC using dodecane as an internal standard.

absorber for acids produced during the reaction, sufficient amounts are necessary to ensure high yields. As shown in Figure $1 \mathrm{~b}$, amounts of $\mathrm{Et}_{3} \mathrm{~N}$ less than $1 \mathrm{mmol}$ led to lower yields of $33 \%$ for $0.5 \mathrm{mmol} \mathrm{Et}_{3} \mathrm{~N}$ and $61 \%$ for $0.8 \mathrm{mmol} \mathrm{Et}_{3} \mathrm{~N}$, respectively. However, a slight excess of $\mathrm{Et}_{3} \mathrm{~N}$ (1.2 mmol) allowed the reaction to be completed with a product yield of $97 \%$. In addition, further increasing the amount of the base was not beneficial for the yield of benzaldehyde $\left(1.5 \mathrm{mmol} \mathrm{Et}_{3} \mathrm{~N}\right.$, 
a)

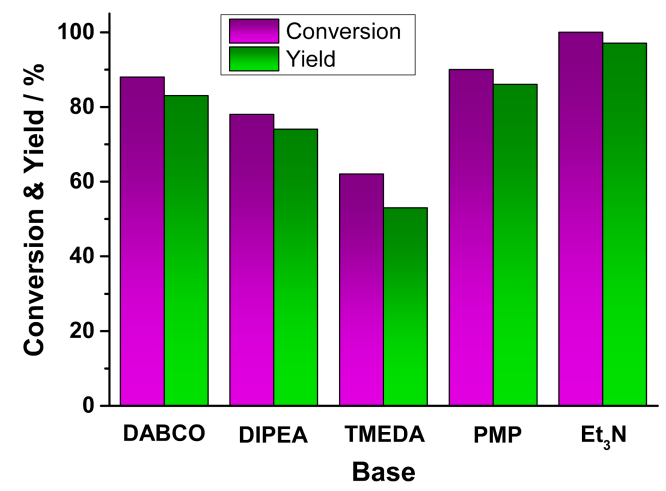

b)

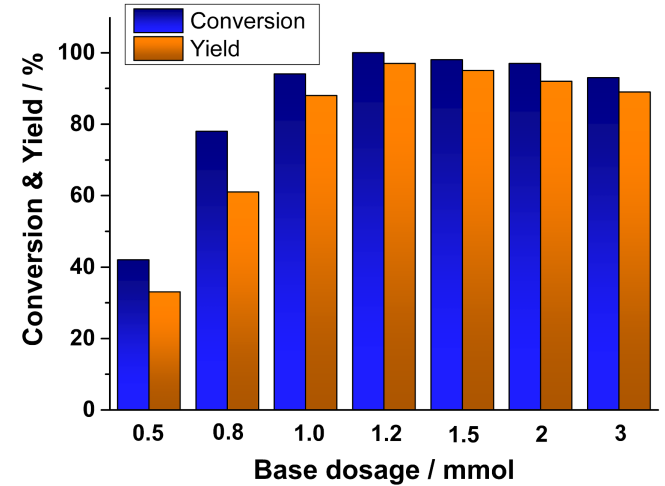

c)

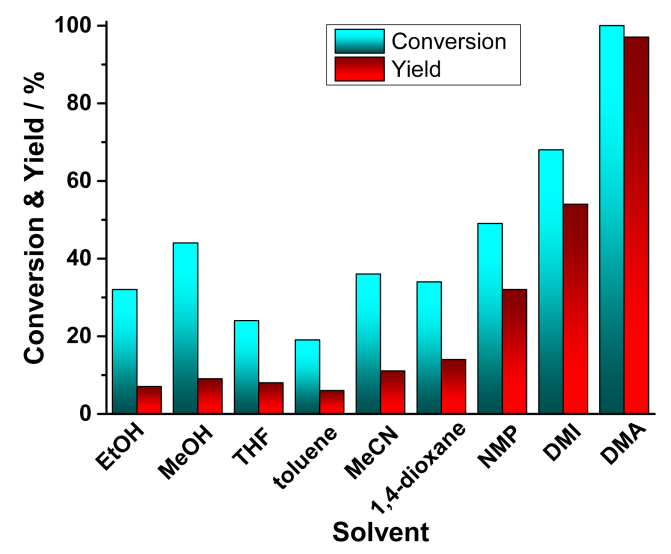

d)

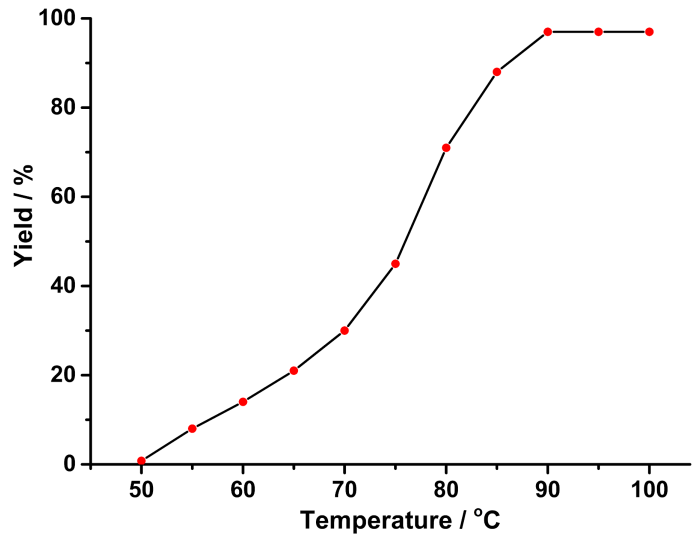

e)

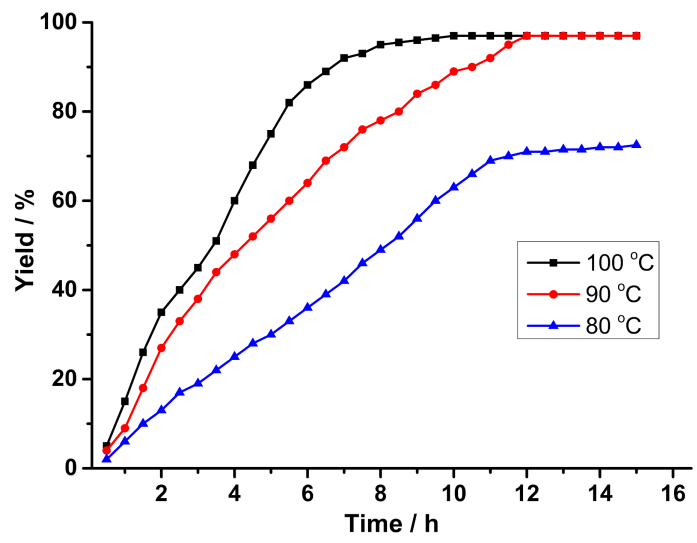

Figure 1: Rhodium-catalyzed reductive carbonylation of iodobenzene with $\mathrm{CO}$ and $\mathrm{H}_{2}$ to afford benzaldehyde. a) Effects of the tested bases; b) effects of base amount; c) effects of tested solvents; d) temperature screen; e) yields at different times for reactions performed at 80,90 and $100{ }^{\circ} \mathrm{C}$ (every point represents an average result of three parallel experiments). Conversions and yields were determined by GC using dodecane as an internal standard. Standard conditions: $\mathrm{Phl}(1 \mathrm{mmol}), \mathrm{RhCl}_{3} \cdot 3 \mathrm{H}_{2} \mathrm{O}(2.5 \mathrm{~mol} \%), \mathrm{PPh}_{3}(10 \mathrm{~mol} \%)$, base (1.2 mmol, if not stated otherwise), DMA ( $2 \mathrm{~mL}$, if not stated otherwise), $\mathrm{CO} / \mathrm{H}_{2}$ (5 bar: 5 bar), temperature $90{ }^{\circ} \mathrm{C}$ (if not stated otherwise), time $12 \mathrm{~h}$ (if not stated otherwise).

95\% yield; $2 \mathrm{mmol} \mathrm{Et}_{3} \mathrm{~N}, 92 \%$ yield; $3 \mathrm{mmol} \mathrm{Et}_{3} \mathrm{~N}, 89 \%$ yield). Thus, the appropriate amount of $\mathrm{Et}_{3} \mathrm{~N}$ was set at $1.2 \mathrm{mmol}$.

\section{Effect of solvents}

Solvents act as the reaction media and strongly influence the catalytic reactions $[52,53]$. We screened nine representative solvents in the catalytic reaction and the results are summarized in Figure 1c. Apparently, protic solvents like EtOH or $\mathrm{MeOH}$ and nonpolar solvents like THF or toluene were inappropriate for the reaction leading to yields lower than $10 \%$. Medium polar solvents like MeCN or 1,4-dioxane afforded slightly higher yields but still below $15 \%$. To our delight, polar solvents with high boiling points, NMP, DMI or DMA proved to be more suitable, and afforded benzaldehyde in $32 \%, 54 \%$ and $97 \%$ yield, respectively, likely owing to the high boiling point and better $\mathrm{CO}$ and $\mathrm{H}_{2}$ dissolution ability, highlighting a strong sol- 
vent dependency of the system $[54,55]$. Therefore, DMA was selected as the most suitable solvent for the reaction.

\section{Effects of temperature and time}

To further optimize the performance of the catalytic system, the effect of the reaction temperature was screened in the range of $50{ }^{\circ} \mathrm{C}$ to $100{ }^{\circ} \mathrm{C}$. The results revealed that the reaction temperature had an important influence on the catalytic process and the product yield increased with increasing temperature. At low temperature the reaction did not proceed at all, however, at $90{ }^{\circ} \mathrm{C}$ or higher, a nearly quantitative yield of benzaldehyde was obtained (Figure 1d). Next, parallel experiments were conducted at three selected temperatures $\left(80{ }^{\circ} \mathrm{C}, 90{ }^{\circ} \mathrm{C}\right.$, and $100{ }^{\circ} \mathrm{C}$ ) to study the yields at different reaction times. The results revealed that equally high yields were obtained at $90{ }^{\circ} \mathrm{C}$ and $100^{\circ}$, but the reaction was much faster at $100^{\circ} \mathrm{C}$ than at $90{ }^{\circ} \mathrm{C}$ (Figure 1e). On the other hand, when performing the reaction at $80^{\circ} \mathrm{C}$, the product yield was lower and required longer times to be reached.

\section{Effects of pressure of $\mathrm{CO}$ and $\mathrm{H}_{2}$}

The influence of the pressures of $\mathrm{CO}$ and $\mathrm{H}_{2}$ was explored next. As expected, a low pressure of both, $\mathrm{CO}$ (1 atm) and $\mathrm{H}_{2}$ ( $1 \mathrm{~atm})$, resulted in a lower yield of benzaldehyde (24\% yield, Table 3, entry 1). When the pressures of both gases were increased to $2,3,4$, or 5 bar, the yield of benzaldehyde accordingly increased to $51 \%, 62 \% 81 \%$, and $97 \%$, respectively (Table 3 , entries 2-5). However, further increasing the pressures did not lead to higher yields (Table 3, entries 6 and 7). After that, we examined the proportions of the syngas components on the reaction and it was found that the optimized proportions of syngas were 5 bar $\mathrm{CO}$ and 5 bar $\mathrm{H}_{2}$ (1:1, (Table 3, entries 8-13).

\section{Scaled-up experiment}

Noteworthy, when conducting the reaction at a larger scale (10 mmol), benzaldehyde was obtained with a high yield of $93 \%$, indicating that our system could be suitable for industrial application (Scheme 1).

\section{Optimal ratio of $\mathrm{Rh}$ salt and $\mathrm{PPh}_{3}$ ligand and active species participating in the catalytic process}

In order to ascertain the optimized ratio of $\mathrm{RhCl}_{3} \cdot 3 \mathrm{H}_{2} \mathrm{O}$ and the $\mathrm{PPh}_{3}$ ligand, a series of experiments with different concentrations and ratios of $\mathrm{RhCl}_{3} \cdot 3 \mathrm{H}_{2} \mathrm{O}$ and $\mathrm{PPh}_{3}$ were conducted. At first, the concentration of $\mathrm{RhCl}_{3} \cdot 3 \mathrm{H}_{2} \mathrm{O}$ was fixed at $1 \mathrm{~mol} \%$. When changing the amount of $\mathrm{PPh}_{3}$ from $2 \mathrm{~mol} \%$ to $5 \mathrm{~mol} \%$, the yield gradually increased reaching a maximum yield of $74 \%$ at $4 \mathrm{~mol} \% \mathrm{PPh}_{3}$. Further increasing the amount of the ligand resulted in a decrease of the product yield (Table 4, entries
Table 3: Rhodium-catalyzed reductive carbonylation of iodobenzene with $\mathrm{CO}$ and $\mathrm{H}_{2}$ to afford benzaldehyde: effect of pressures of $\mathrm{CO}$ and $\mathrm{H}_{2}{ }^{\mathrm{a}}$.

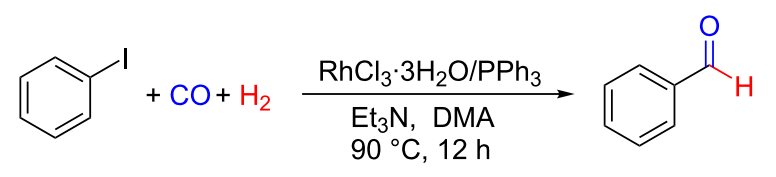

\begin{tabular}{lllll}
\hline Entry & $\begin{array}{l}p(\mathrm{CO}) \\
{[\mathrm{bar}]}\end{array}$ & $\begin{array}{l}p\left(\mathrm{H}_{2}\right) \\
{[\mathrm{bar}]}\end{array}$ & $\begin{array}{l}\text { Conversion } \\
{[\%]^{b}}\end{array}$ & $\begin{array}{l}\text { Yield } \\
{[\%]^{\mathrm{b}}}\end{array}$ \\
\hline 1 & 1 & 1 & 32 & 24 \\
2 & 2 & 2 & 63 & 51 \\
3 & 3 & 3 & 74 & 62 \\
4 & 4 & 4 & 92 & 81 \\
5 & 5 & 5 & 100 & 97 \\
6 & 6 & 6 & 100 & 97 \\
7 & 7 & 7 & 100 & 97 \\
8 & 2 & 4 & 72 & 63 \\
9 & 4 & 2 & 66 & 58 \\
10 & 3 & 6 & 85 & 72 \\
11 & 6 & 3 & 74 & 68 \\
12 & 4 & 6 & 99 & 94 \\
13 & 6 & 4 & 95 & 89 \\
\hline
\end{tabular}

aStandard conditions: $\mathrm{Phl}(1 \mathrm{mmol}), \mathrm{RhCl}_{3} \cdot 3 \mathrm{H}_{2} \mathrm{O}(2.5 \mathrm{~mol} \%), \mathrm{PPh}_{3}$ (10 mol \%), $\mathrm{Et}_{3} \mathrm{~N}(1.2 \mathrm{mmol}), \mathrm{DMA}(2 \mathrm{~mL}), \mathrm{CO} / \mathrm{H}_{2}, 90{ }^{\circ} \mathrm{C}, 12 \mathrm{~h}$. betermined by GC using dodecane as an internal standard.

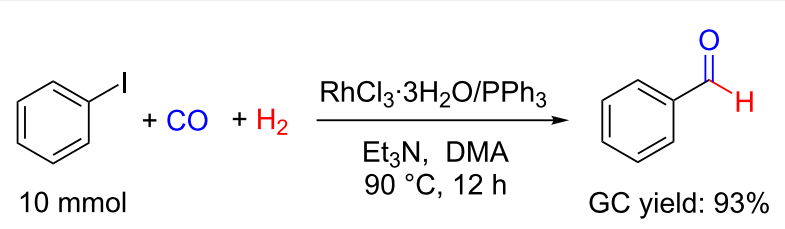

Scheme 1: Scaled-up experiment of the reductive carbonylation of iodobenzene to benzaldehyde under the optimized conditions.

1-4). Next, the concentration of $\mathrm{RhCl}_{3} \cdot 3 \mathrm{H}_{2} \mathrm{O}$ was increased to $2 \mathrm{~mol} \%$ and $2.5 \mathrm{~mol} \%$, leading to the same results. In other words, the optimal ratio of $\mathrm{RhCl}_{3} \cdot 3 \mathrm{H}_{2} \mathrm{O}$ and the $\mathrm{PPh}_{3}$ ligand was always 1:4 (Table 4, entries 5-12). No higher yields (Table 4, entries 13-15) could be obtained by increasing the loadings of $\mathrm{RhCl}_{3} \cdot 3 \mathrm{H}_{2} \mathrm{O}$ and $\mathrm{PPh}_{3}$.

The effects of $\mathrm{PPh}_{3}$ dosage on the catalytic ability demonstrated that under otherwise identical conditions, a maximum yield of benzaldehyde (97\%) was obtained with a 1:4 molar ratio of $\mathrm{RhCl}_{3} \cdot 3 \mathrm{H}_{2} \mathrm{O} / \mathrm{PPh}_{3}$, while higher or lower concentrations of $\mathrm{PPh}_{3}$ both led to decreased yields (Table 4). This indicated that in the active catalytic species the molar ratio of [Rh]: $\mathrm{PPh}_{3}$ was exactly 1:3 (not 1:4 because of the consumption of 1 equiv $\mathrm{PPh}_{3}$ during the redox process), which might be $\mathrm{Rh}\left(\mathrm{PPh}_{3}\right)_{3} \mathrm{Cl}$. The mentioned redox reaction can be explained 
Table 4: Rhodium-catalyzed reductive carbonylation of iodobenzene with $\mathrm{CO}$ and $\mathrm{H}_{2}$ to afford benzaldehyde: effects of dosage of $\mathrm{RhCl}_{3} \cdot 3 \mathrm{H}_{2} \mathrm{O}$ and $\mathrm{PPh}_{3}{ }^{\mathrm{a}}$

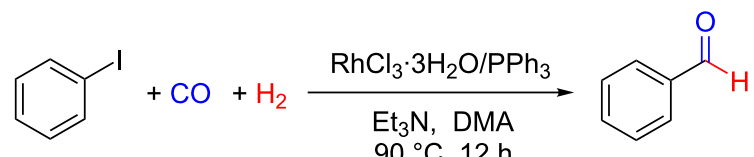

Entry $\quad \mathrm{RhCl}_{3} \cdot 3 \mathrm{H}_{2} \mathrm{O} \quad \mathrm{PPh}_{3} \quad$ Conversion Yield
$[\mathrm{mol} \%] \quad[\mathrm{mol} \%] \quad[\%]^{\mathrm{b}} \quad[\%]^{\mathrm{b}}$

\begin{tabular}{lllll}
\hline 1 & 1 & 2 & 35 & 28 \\
2 & 1 & 3 & 51 & 47 \\
3 & 1 & 4 & 78 & 74 \\
4 & 1 & 5 & 72 & 70 \\
5 & 2 & 4 & 34 & 31 \\
6 & 2 & 6 & 65 & 62 \\
7 & 2 & 8 & 92 & 88 \\
8 & 2 & 10 & 88 & 84 \\
9 & 2.5 & 5 & 47 & 42 \\
10 & 2.5 & 7.5 & 81 & 73 \\
11 & 2.5 & 10 & 100 & 97 \\
12 & 2.5 & 12.5 & 100 & 92 \\
13 & 3 & 12 & 100 & 97 \\
14 & 4 & 16 & 100 & 97 \\
15 & 5 & 20 & 100 & 97 \\
\hline
\end{tabular}

aStandard conditions: $\mathrm{Phl}(1 \mathrm{mmol}), \mathrm{RhCl}_{3} \cdot 3 \mathrm{H}_{2} \mathrm{O}, \mathrm{PPh}_{3}, \mathrm{Et}_{3} \mathrm{~N}$ (1.2 mmol), DMA (2 mL), CO/ $\mathrm{H}_{2}$ (5 bar:5 bar), $90^{\circ} \mathrm{C}, 12 \mathrm{~h}$. betermined by GC using dodecane as an internal standard.

as shown in Scheme 2a. Initially, $\mathrm{RhCl}_{3} \cdot 3 \mathrm{H}_{2} \mathrm{O}$ is reduced by 1 equiv $\mathrm{PPh}_{3}$ to form a $\mathrm{Rh}(\mathrm{I})$ species that subsequently combines with 3 equiv $\mathrm{PPh}_{3}$ forming $\mathrm{Rh}\left(\mathrm{PPh}_{3}\right)_{3} \mathrm{Cl}$. During this process $\mathrm{PPh}_{3}$ is oxidized to $\mathrm{O}=\mathrm{PPh}_{3}$, and $\mathrm{HCl}$ and $\mathrm{H}_{2} \mathrm{O}$ are released.
To test this assumption, we synthesized $\mathrm{Rh}\left(\mathrm{PPh}_{3}\right)_{3} \mathrm{Cl}$ according to the literature [56] on account of no commercial sources and employed it as the catalyst in the reaction instead of $\mathrm{RhCl}_{3} \cdot 3 \mathrm{H}_{2} \mathrm{O}$ and $\mathrm{PPh}_{3}$ and a $93 \%$ yield of benzaldehyde was obtained under otherwise identical reaction conditions (Scheme 2b). This could be an evidence that after the reduction of one equivalent $\mathrm{RhCl}_{3}$ complexation with three molecular $\mathrm{PPh}_{3}$ takes place forming $\mathrm{Rh}\left(\mathrm{PPh}_{3}\right)_{3} \mathrm{Cl}$, which participated in the subsequent catalytic process. Herein, $\mathrm{Rh}$ (III) is reduced to $\mathrm{Rh}(\mathrm{I})$, with concomitant oxidation of $\mathrm{PPh}_{3}$ to $\mathrm{PPh}_{3}=\mathrm{O}$. A quite interesting fact is that $\mathrm{Rh}\left(\mathrm{PPh}_{3}\right)_{3} \mathrm{Br}$ and $\mathrm{Rh}\left(\mathrm{PPh}_{3}\right)_{3} \mathrm{I}$ afforded much lower yields of the aldehyde compared to $\mathrm{Rh}\left(\mathrm{PPh}_{3}\right)_{3} \mathrm{Cl}$ although they share the identical metal center and ligand (Scheme $2 \mathrm{c}$ and $2 \mathrm{~d}$ ). This indicated that the anion plays an important role in the catalytic process.

\section{Substrate scope}

Next, the scope of the reductive carbonylation reaction was explored (shown in Scheme 3), after having identified the optimized conditions for benzaldehyde synthesis from iodobenzene. The results showed that electronic effects had little impact on the reaction. Both, substrates with electron-withdrawing or electron-donating groups afforded similar yields. However, steric effects played an important role in the catalytic process, i.e., the yields were influenced by the substituent group positions following the order of ortho < meta < para. The obtained isolated yields were slightly lower than the NMR yields owing to a loss of products during the workup process. Iodobenzene with no substituent group provided benzaldehyde (1) with $93 \%$ yield. For iodobenzene derivatives with electron-donating groups (Me, OMe), 83-95\% yield of aldehydes 2-7 were obtained. As expected, the yields increased in the order of ortho $<$ meta $<$ para-substituted compounds. As for aryl iodides with halide

a) $\mathrm{RhCl}_{3} \cdot 3 \mathrm{H}_{2} \mathrm{O}+4 \mathrm{PPh}_{3} \longrightarrow \mathrm{RhCl}\left(\mathrm{PPh}_{3}\right)_{3}+\mathrm{O}=\mathrm{PPh}_{3}+2 \mathrm{HCl}+2 \mathrm{H}_{2} \mathrm{O}$

b)

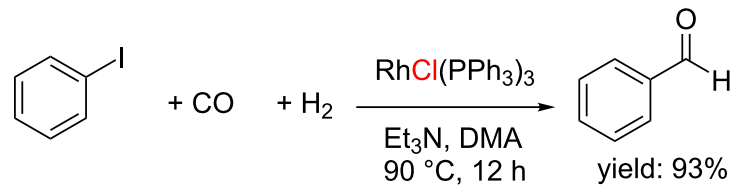

c)

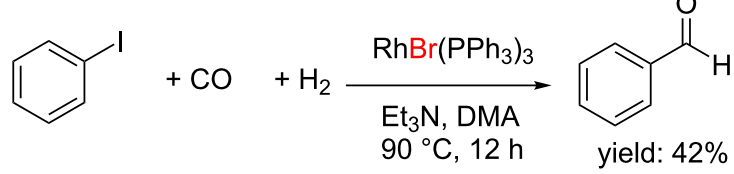

d)

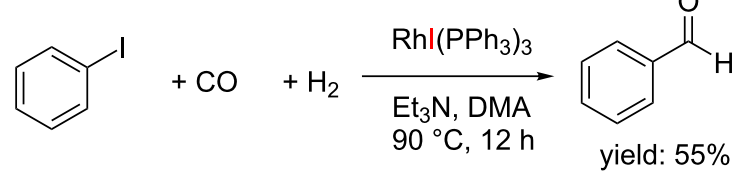




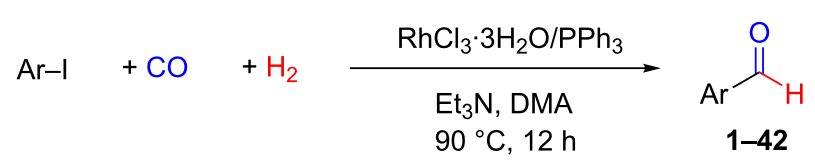

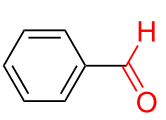

$1,93 \%$

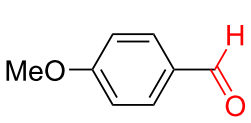

7, $92 \%$<smiles>O=Cc1ccc(Cl)cc1</smiles>

$13,89 \%$

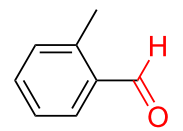

2, $84 \%$

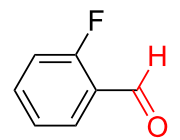

8, $80 \%$

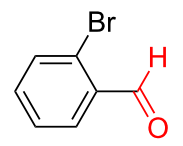

$14,79 \%$<smiles>O=Cc1ccc2ccccc2c1</smiles>

$19,84 \%$<smiles>O=Cc1cccc2ccccc12</smiles>

$20,77 \%$

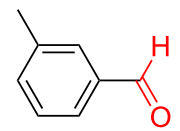

3, $90 \%$

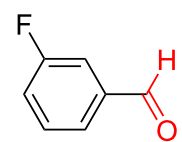

9, $82 \%$

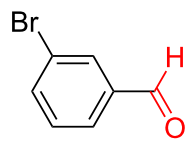

$15,82 \%$<smiles>Cc1cccc(C)c1C=O</smiles>

21, $61 \%$

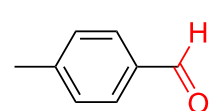

4, $95 \%$

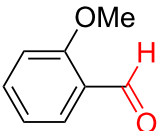

5, $83 \%$

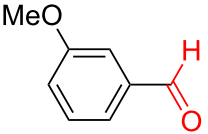

6, $88 \%$<smiles>O=Cc1ccc(F)cc1</smiles>

$10,88 \%$

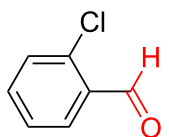

$11,81 \%$

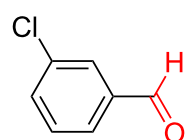

$12,84 \%$<smiles>CC(=O)c1ccc(C=O)cc1</smiles>

$25,87 \%$<smiles>O=Cc1ccc2c(c1)OCO2</smiles>

26, $92 \%$<smiles>CC(=O)Nc1ccc(C=O)cc1</smiles>

$27,82 \%$<smiles>O=Cc1ccc(Br)cc1</smiles>

$16,86 \%$<smiles>Cc1cc(C)c(C=O)c(C)c1</smiles>

22, $60 \%$<smiles>O=Cc1ccc(-c2ccccc2)cc1</smiles>

$17,85 \%$<smiles>CC(=O)c1ccccc1C=O</smiles>

23, $79 \%$<smiles>[13CH2]c1ccc(C=O)cc1</smiles>

$18,81 \%$<smiles>O=Cc1ccc(C(F)(F)F)cc1</smiles>

28, $79 \%$<smiles>O=Cc1cc(C(F)(F)F)cc(C(F)(F)F)c1</smiles>

29, $75 \%$<smiles>CC(=O)c1cccc(C=O)c1</smiles>

$24,81 \%$<smiles>N#Cc1ccc(C=O)cc1</smiles>

$31,77 \%$<smiles>O=Cc1ccc(F)cc1F</smiles>

$32,76 \%$<smiles>O=Cc1ccco1</smiles>

$38,65 \%$<smiles>O=Cc1ccc(Cl)cc1Cl</smiles>

$33,78 \%$<smiles>O=Cc1ccc(Cl)c(F)c1</smiles>

$34,81 \%$<smiles>O=Cc1ccc(Br)c(F)c1</smiles>

$35,80 \%$<smiles>O=Cc1cccnc1</smiles>

41, $71 \%$<smiles>O=Cc1ccc(C(F)(F)F)cc1C(F)(F)F</smiles>

$30,72 \%$<smiles>O=Cc1ccsc1</smiles>

$37,68 \%$<smiles>O=Cc1ccoc1</smiles>

$39,66 \%$

$40,70 \%$

Scheme 3: Substrate scope for the Rh-catalyzed reductive carbonylation of aryl iodides using $\mathrm{CO}$ and $\mathrm{H}_{2}$. Reaction conditions: Phl (1 mmol), $\mathrm{RhCl}_{3} \cdot 3 \mathrm{H}_{2} \mathrm{O}(2.5 \mathrm{~mol} \%), \mathrm{PPh}_{3}(10 \mathrm{~mol} \%), \mathrm{Et}_{3} \mathrm{~N}(1.2 \mathrm{mmol}), \mathrm{DMA}(2 \mathrm{~mL}), \mathrm{CO}(5 \mathrm{bar}), \mathrm{H}_{2}(5 \mathrm{bar}), 90^{\circ} \mathrm{C}, 12 \mathrm{~h}$. Isolated yields of the products are given and the structures were determined by NMR. Detailed information is given in Supporting Information File 1.

substituents $(\mathrm{F}, \mathrm{Cl}, \mathrm{Br})$, these were also compatible with the reaction system, affording $79-89 \%$ yields of the halogenated aromatic aldehydes 8-16. Iodobenzene derivatives with phenyl or tert-butyl groups displaying larger steric hindrance in the para- position still provided the corresponding aldehydes $\mathbf{1 7}$ and $\mathbf{1 8}$ in relatively high yields ( $85 \%$ and $81 \%$, respectively). 2-Iodonaphthalene with smaller steric hindrance performed a little better than 1-iodonaphthalene (19, 84\% and 20, 77\%). However, 
starting iodides having methyl substituents in both ortho-positions afforded the corresponding aldehydes in much lower yields (21 61\% and 22 60\%). Also, iodobenzenes with an acetyl group in either ortho, meta, or para-position gave the products in satisfactory yields (23 79\%, $2481 \%$ and $\mathbf{2 5} 87 \%$ ). 1-Iodo3,4-methylenedioxybenzene performed well providing aldehyde 26 with $92 \%$ yield. Aryl iodide with an acetamido group in the para-position gave a medium yield (27 82\%). Aryl iodides containing one or two trifluoromethyl groups in their structure worked slightly less efficient producing arylaldehydes 28-30 with yields of $72-79 \%$. It is worth noticing that a cyano group in the substrate stayed intact in the catalytic process giving aldehyde 31 with $77 \%$ yield. Also substrates comprising two halogen substituents performed well offering access to dihalogenated aldehydes 32-35 with yields between 76-81\%. In addition, heterocyclic iodides were also amenable to the reductive carbonylation reaction and the corresponding aldehydes 36-42 were isolated with yields of $65-73 \%$.

\section{Isotope labeling experiments}

Isotope labeling experiments were conducted to study the mechanism of the reductive carbonylation of aryl iodide with $\mathrm{CO}$ and $\mathrm{H}_{2}$ under our optimized conditions, using ${ }^{13} \mathrm{CO}$ and $\mathrm{D}_{2}$ instead of $\mathrm{CO}$ and $\mathrm{H}_{2}$, respectively, as the sources of the carbonyl group and hydrogen in the formyl group. $\mathrm{C}_{6} \mathrm{H}_{5}{ }^{13} \mathrm{CHO}$, $\mathrm{C}_{6} \mathrm{H}_{5} \mathrm{CDO}$, and $\mathrm{C}_{6} \mathrm{H}_{5}{ }^{13} \mathrm{CDO}$ could be verified by the molecular ion peaks at $m / z 107,107$, and 108 in the GC-MS spectrum of the reaction solution (for the spectrum, see Supporting Information File 1). This result confirmed that both $\mathrm{CO}$ and $\mathrm{H}_{2}$ participated in the formation of the formyl group in the product (Scheme 4a-c).

(a)<smiles>CCO[N+](=O)c1cccc(C=O)c1</smiles>

(b)<smiles>[2H]C(=O)c1ccc(-c2ccccc2)cc1</smiles>

(c)<smiles>[2H]C(=O)c1ccc(-c2ccccc2)cc1</smiles>

Scheme 4: Isotope-labeling experiments.

\section{Reaction mechanism and role of each component}

Based on the results from the labeling experiments a reaction mechanism for the reductive carbonylation of aryl iodides was proposed, as shown in Scheme 5 [57]. First, $\mathrm{RhCl}_{3} \cdot 3 \mathrm{H}_{2} \mathrm{O}$ reacted with $\mathrm{PPh}_{3}$ to form $\mathrm{Rh}\left(\mathrm{PPh}_{3}\right)_{3} \mathrm{Cl}(\mathbf{A})$, followed by an oxidative addition of $\mathrm{Rh}\left(\mathrm{PPh}_{3}\right)_{3} \mathrm{Cl}$ (A) to the aryl iodide, producing the corresponding arylrhodium complex $(\mathbf{B})$. Then, the coordination and insertion of $\mathrm{CO}$ led to the formation of benzoylrhodium complex (C). Next, metathesis with $\mathrm{H}_{2}$ afforded the aldehyde product. The base, $\mathrm{Et}_{3} \mathrm{~N}$ neutralized the proton in the rhodium hydroiodide complex (D) and regenerated the active $\mathrm{Rh}$ species [11].

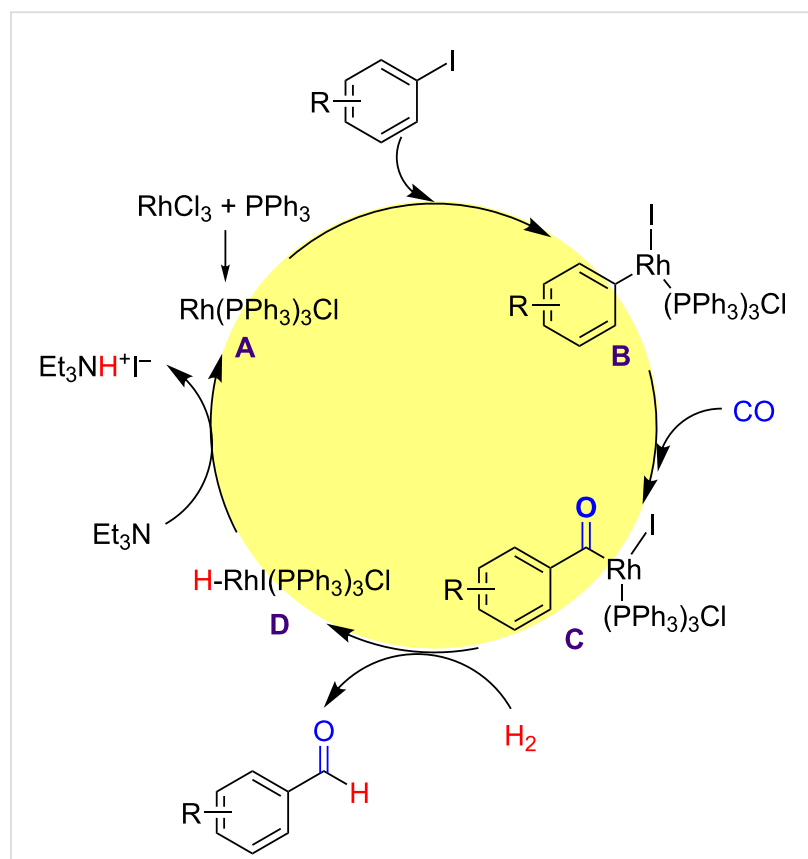

Scheme 5: Proposed reaction mechanism for the $\mathrm{Rh}$-catalyzed reductive carbonylation of aryl iodides using $\mathrm{CO}$ and $\mathrm{H}_{2}$.

In the catalytic system, $\mathrm{CO}$ and $\mathrm{H}_{2}$ (or syngas) were used as the carbonyl and hydrogen sources, respectively. The catalyst $\mathrm{RhCl}_{3} \cdot 3 \mathrm{H}_{2} \mathrm{O}$ and $\mathrm{PPh}_{3}$ reacted via a redox reaction to form $\mathrm{Rh}\left(\mathrm{PPh}_{3}\right)_{3} \mathrm{Cl}$, which is the active catalytic species able to activate $\mathrm{C}-\mathrm{I}$ bonds in the aryl iodides for the insertion of $\mathrm{CO}$ in the next step. The base $\mathrm{Et}_{3} \mathrm{~N}$ neutralized the proton in the intermediate rhodium hydroiodide (D) complex and regenerated the active $\mathrm{Rh}$ species completing the catalytic cycle.

\section{Conclusion}

An efficient and facile $\mathrm{Rh}$-based catalytic system composed of a commercially available $\mathrm{Rh}$ salt, $\mathrm{RhCl}_{3} \cdot 3 \mathrm{H}_{2} \mathrm{O}$, a phosphine ligand $\mathrm{PPh}_{3}$, and a base $\mathrm{Et}_{3} \mathrm{~N}$, was evaluated for the synthesis of arylaldehydes via the reductive carbonylation of aryl iodides using $\mathrm{CO}$ as carbonyl source and $\mathrm{H}_{2}$ as hydrogen source under relatively mild conditions with a broad substrate range. The low gas pressure, cost-effective ligand and low metal dosage significantly improved the practicability of the system for industrial 
productions. Another advantage of the method includes the use of cheap and abundant syngas (mixtures of $\mathrm{CO}$ and $\mathrm{H}_{2}$ ) in the catalytic system as an effective and convenient formyl source at relatively low pressures, which further enhanced the possibility of practical application of the proposed system.

\section{Experimental Materials}

Rhodium species $\left(\left[\mathrm{RhCl}(\mathrm{CO})_{2}\right]_{2}, \mathrm{RhCl}(\mathrm{CO})\left(\mathrm{PPh}_{3}\right)_{2}\right.$, $\mathrm{Rh}(\mathrm{acac})(\mathrm{CO})_{2},[\mathrm{RhCl}(\mathrm{COD})]_{2}, \mathrm{Rh}(\mathrm{MeCN})_{2}(\mathrm{COD}) \mathrm{BF}_{4}$, $\mathrm{Rh}(\mathrm{COD}) \mathrm{BF}_{4}, \mathrm{Rh}(\mathrm{COD})_{2} \mathrm{OTf},[\mathrm{Rh}(\mathrm{OMe})(\mathrm{COD})]_{2}, \mathrm{Rh}(\mathrm{OAc})_{2}$ $\left[\mathrm{Rh}\left(\mathrm{CF}_{3} \mathrm{COO}\right)\right]_{2},\left[\mathrm{Rh}\left(\mathrm{CH}_{3}\left(\mathrm{CH}_{2}\right)_{6} \mathrm{CO}_{2}\right)_{2}\right]_{2}, \mathrm{Rh}(\mathrm{acac})_{3}, \mathrm{Rh}($ ethylene) ${ }_{2}$ (acac), $\left[\mathrm{Rh} \text { (ethylene) }{ }_{2} \mathrm{Cl}\right]_{2}, \mathrm{Rh}$ (norbornadiene) ${ }_{2} \mathrm{BF}_{4}$, $\left[\mathrm{Cp} * \mathrm{RhCl}_{2}\right]_{2}, \mathrm{Rh} / \mathrm{C}$, and $\left.\mathrm{RhCl}_{3} \cdot 3 \mathrm{H}_{2} \mathrm{O}\right)$, ligands containing nitrogen or phosphorus $\left(\mathrm{PP}_{3}\right.$, triphos, dpp-BINAP, dpp-OPh, dppb, dppe, $\mathrm{P}\left(\mathrm{PhF}_{5}\right)_{3}, \mathrm{P}(4-\mathrm{FPh})_{3}, \mathrm{Cydpp}$, Bipy, DBU, Im, and $\mathrm{PPh}_{3}$ (their structures are shown in Table 2)), bases $\left(\mathrm{Et}_{3} \mathrm{~N}, 1,4-\right.$ diaza[2.2.2]bicyclooctane (DABCO), $N, N$-diisopropylethylamine (DIPEA), $N, N, N^{\prime}, N^{\prime}$-tetramethylethylenediamine (TMEDA) and 1,2,2,6,6-pentamethylpiperidine (PMP)), and solvents ( $N, N$-dimethylacetamide (DMA), 1,3-dimethyl-2imidazolidinone (DMI), $N$-methyl-2-pyrrolidinone (NMP), tetrahydrofuran (THF), 1,4-dioxane, ethanol, methanol, acetonitrile, and toluene) together with aryl iodides and other reagents were purchased from commercial sources (namely J\&K Scientific Ltd. and Innochem Science \& Technology Co., Ltd.) and used without further purification. $\mathrm{CO}$ and $\mathrm{H}_{2}$ with high purity (99.99\%) were supplied by Beijing Analytical Instrument Factory.

\section{Instrumentation}

${ }^{1} \mathrm{H}$ NMR spectra in solution were recorded in $\mathrm{CDCl}_{3}$ using the residual $\mathrm{CHCl}_{3}$ as internal reference (7.26 ppm) on a Bruker 400 spectrometer. ${ }^{1} \mathrm{H}$ NMR peaks were labeled as singlet (s), doublet (d), triplet (t), and multiplet (m). The coupling constants, $J$, are reported in hertz $(\mathrm{Hz}) .{ }^{13} \mathrm{C}$ NMR spectra in solution were recorded at $101 \mathrm{MHz}$ in $\mathrm{CDCl}_{3}$ using the solvent as internal reference $(77.0 \mathrm{ppm})$. GC analysis was performed on Agilent 4890D with a FID detector and a nonpolar capillary column (DB-5) $(30 \mathrm{~m} \times 0.25 \mathrm{~mm} \times 0.25 \mu \mathrm{m})$. The column oven was temperature-programmed with a 2 min initial hold at $50{ }^{\circ} \mathrm{C}$, followed by heating to $265{ }^{\circ} \mathrm{C}$ at a rate of $10{ }^{\circ} \mathrm{C} / \mathrm{min}$ and kept at $265{ }^{\circ} \mathrm{C}$ for $10 \mathrm{~min}$. High purity nitrogen was used as the carrier gas.

\section{General procedure for reductive carbonylation of aryl iodides with $\mathrm{CO}$ and $\mathrm{H}_{2}$}

All reactions were carried out in an $80 \mathrm{~mL}$ Teflon-lined stainless steel reactor equipped with a magnetic stirring bar. Typically, in a glovebox, the aryl iodides $(1.0 \mathrm{mmol}), \mathrm{RhI}_{3}$ (0.025 mmol), $\mathrm{PPh}_{3}(0.1 \mathrm{mmol}), \mathrm{Et}_{3} \mathrm{~N}$ (1.2 mmol), and DMA
$(2 \mathrm{~mL})$ were loaded into the reactor. Then, the autoclave was screwed up, charged with $\mathrm{CO}$ and $\mathrm{H}_{2}$ to a total pressure of 10 bar (1:1) and transferred to an oil bath preheated at $90{ }^{\circ} \mathrm{C}$, which was controlled by a Haake-D3 temperature controller. After completion of the reaction, the reactor was cooled in iced water and the gas carefully vented. The conversion and yield of the aryl iodides and arylaldehydes were determined by GC analysis using dodecane as an internal standard. For yield determination of the other products, the reaction mixture was first analyzed by GC-MS to determine the structures of the aromatic aldehyde products. Then, $\mathrm{CH}_{2} \mathrm{Cl}_{2}(5 \mathrm{~mL})$ was added to the reaction mixture, after which deionized water $(10 \mathrm{~mL})$ was added to extract the solvent DMA for 5 times. The organic layer was dried over anhydrous $\mathrm{Na}_{2} \mathrm{SO}_{4}$, concentrated by rotary evaporation and finally purified by column chromatography on silica gel using $n$-hexane/ethyl acetate as eluent to obtain the pure products and isolated yields.

\section{Procedures for the preparations of $\mathrm{RhCl}\left(\mathrm{PPh}_{3}\right)_{3}, \mathrm{RhBr}\left(\mathrm{PPh}_{3}\right)_{3}$ and $\mathrm{Rhl}\left(\mathrm{PPh}_{3}\right)_{3}$}

Preparation of $\mathrm{RhCl}\left(\mathrm{PPh}_{3}\right)_{3}$ : A round-bottomed flask filled with anhydrous ethanol $(60 \mathrm{~mL})$ and triphenylphosphine $(10 \mathrm{mmol})$ was put in an oil bath at $70{ }^{\circ} \mathrm{C}$ under a nitrogen atmosphere. Then, hydrated rhodium(III) chloride $(1.5 \mathrm{mmol})$ dissolved in anhydrous ethanol $(10 \mathrm{~mL})$ was added to the solution under stirring and the resulting solution was kept at gentle reflux for $2.5 \mathrm{~h}$. Afterwards, the hot mixture was filtered. Finally, the solid was washed with ether and dried under vacuum overnight to afford $\mathrm{RhCl}\left(\mathrm{PPh}_{3}\right)_{3}$ as maroon powder. The preparations of $\mathrm{RhBr}\left(\mathrm{PPh}_{3}\right)_{3}$ and $\mathrm{RhI}\left(\mathrm{PPh}_{3}\right)_{3}$ were similar only with different halide ions.

\section{Supporting Information}

\section{Supporting Information File 1}

MS spectra of isotope-labeling experiments and

characterization of products.

[https://www.beilstein-journals.org/bjoc/content/ supplementary/1860-5397-16-61-S1.pdf]

\section{Acknowledgements}

We thank Institute of Chemistry, Chinese Academy of Sciences for the supply of $\mathrm{CO}$ gas and corresponding safety protection.

\section{Funding}

This work was supported by the National Natural Science Foundation of China (21773307), Zhejiang Provincial Natural Science Foundation of China (LTY20B050001) and Zhejiang Provincial Basic Public Welfare Research Project (LGG19B060002). 


\section{ORCID ${ }^{\circledR}$ iDs}

Zhenghui Liu - https://orcid.org/0000-0003-0559-4517

Tiancheng Mu - https://orcid.org/0000-0001-8931-6113

\section{References}

1. Brennführer, A.; Neumann, H.; Beller, M. Angew. Chem., Int. Ed. 2009, 48, 4114-4133. doi:10.1002/anie.200900013

2. Balme, G.; Bossharth, E.; Monteiro, N. Eur. J. Org. Chem. 2003, 4101-4111. doi:10.1002/ejoc.200300378

3. Stambouli, A. B.; Traversa, E. Renewable Sustainable Energy Rev. 2002, 6, 433-455. doi:10.1016/s1364-0321(02)00014-x

4. Tsarevsky, N. V.; Matyjaszewski, K. Chem. Rev. 2007, 107, 2270-2299. doi:10.1021/cr050947p

5. Zhu, C.; Guo, S.; Fang, Y.; Dong, S. ACS Nano 2010, 4, 2429-2437. doi: $10.1021 / \mathrm{nn} 1002387$

6. Peng, J.-B.; Wu, X.-F. Angew. Chem., Int. Ed. 2018, 57, 1152-1160. doi:10.1002/anie.201709807

7. Friis, S. D.; Lindhardt, A. T.; Skrydstrup, T. Acc. Chem. Res. 2016, 49, 594-605. doi:10.1021/acs.accounts.5b00471

8. Franke, R.; Selent, D.; Börner, A. Chem. Rev. 2012, 112, 5675-5732. doi:10.1021/cr3001803

9. Schoenberg, A.; Heck, R. F. J. Am. Chem. Soc. 1974, 96, 7761-7764. doi:10.1021/ja00832a024

10. Klaus, S.; Neumann, H.; Zapf, A.; Strübing, D.; Hübner, S.; Almena, J.; Riermeier, T.; Groß, P.; Sarich, M.; Krahnert, W.-R.; Rossen, K.; Beller, M. Angew. Chem., Int. Ed. 2006, 45, 154-158. doi:10.1002/anie.200502697

11. Sergeev, A. G.; Spannenberg, A.; Beller, M. J. Am. Chem. Soc. 2008, 130, 15549-15563. doi:10.1021/ja804997z

12. Dong, K.; Sang, R.; Fang, X.; Franke, R.; Spannenberg, A.; Neumann, H.; Jackstell, R.; Beller, M. Angew. Chem., Int. Ed. 2017, 56, 5267-5271. doi:10.1002/anie.201700317

13. Dong, K.; Fang, X.; Gülak, S.; Franke, R.; Spannenberg, A.; Neumann, H.; Jackstell, R.; Beller, M. Nat. Commun. 2017, 8, 14117. doi:10.1038/ncomms14117

14. Gong, J.; Yue, H.; Zhao, Y.; Zhao, S.; Zhao, L.; Lv, J.; Wang, S.; Ma, X. J. Am. Chem. Soc. 2012, 134, 13922-13925. doi:10.1021/ja3034153

15. Spivey, J. J.; Egbebi, A. Chem. Soc. Rev. 2007, 36, 1514-1528. doi:10.1039/b414039g

16. Zhong, L.; Yu, F.; An, Y.; Zhao, Y.; Sun, Y.; Li, Z.; Lin, T.; Lin, Y.; Qi, X.; Dai, Y.; Gu, L.; Hu, J.; Jin, S.; Shen, Q.; Wang, H. Nature 2016, 538, 84-87. doi:10.1038/nature19786

17. Corey, J. Y. Chem. Rev. 2016, 116, 11291-11435. doi:10.1021/acs.chemrev.5b00559

18. Gao, M.; Wang, Y.-C.; Yang, K.-R.; He, W.; Yang, X.-L.; Yao, Z.-J. Angew. Chem., Int. Ed. 2018, 57, 13313-13318. doi:10.1002/anie.201808517

19. Picazo, E.; Morrill, L. A.; Susick, R. B.; Moreno, J.; Smith, J. M.; Garg, N. K. J. Am. Chem. Soc. 2018, 140, 6483-6492. doi:10.1021/jacs.8b03404

20. Shi, H.; Michaelides, I. N.; Darses, B.; Jakubec, P.; Nguyen, Q. N. N.; Paton, R. S.; Dixon, D. J. J. Am. Chem. Soc. 2017, 139, 17755-17758. doi:10.1021/jacs.7b10956

21. Klankermayer, J.; Wesselbaum, S.; Beydoun, K.; Leitner, W. Angew. Chem., Int. Ed. 2016, 55, 7296-7343. doi:10.1002/anie.201507458

22. Klankermayer, J.; Leitner, W. Science 2015, 350, 629-630. doi:10.1126/science.aac7997
23. Álvarez, A.; Bansode, A.; Urakawa, A.; Bavykina, A. V.; Wezendonk, T. A.; Makkee, M.; Gascon, J.; Kapteijn, F. Chem. Rev. 2017, 117, 9804-9838. doi:10.1021/acs.chemrev.6b00816

24. Chen, P.; Wu, X.; Lin, J.; Tan, K. L. Science 1999, 285, 91-93. doi:10.1126/science.285.5424.91

25. Kubas, G. J. Chem. Rev. 2007, 107, 4152-4205. doi:10.1021/cr050197j

26. Le Goff, A.; Artero, V.; Jousselme, B.; Tran, P. D.; Guillet, N.; Metaye, R.; Fihri, A.; Palacin, S.; Fontecave, M. Science 2009, 326, 1384-1387. doi:10.1126/science.1179773

27. Yu, X.; Yang, Z.; Guo, S.; Liu, Z.; Zhang, H.; Yu, B.; Zhao, Y.; Liu, Z. Chem. Commun. 2018, 54, 7633-7636. doi:10.1039/c8cc03346c

28. Yu, B.; Yang, Z.; Zhao, Y.; Hao, L.; Zhang, H.; Gao, X.; Han, B.; Liu, Z. Chem. - Eur. J. 2016, 22, 1097-1102. doi:10.1002/chem.201504320

29. Yu, B.; Zhao, Y.; Zhang, H.; Xu, J.; Hao, L.; Gao, X.; Liu, Z. Chem. Commun. 2014, 50, 2330-2333. doi:10.1039/c3cc49365b

30. Neumann, H.; Kadyrov, R.; Wu, X.-F.; Beller, M. Chem. - Asian J. 2012, 7, 2213-2216. doi:10.1002/asia.201200462

31. Singh, A. S.; Bhanage, B. M.; Nagarkar, J. M. Tetrahedron Lett. 2011, 52, 2383-2386. doi:10.1016/j.tetlet.2011.02.097

32. Klaus, S.; Neumann, H.; Zapf, A.; Strübing, D.; Hübner, S.; Almena, J.; Riermeier, T.; Groß, P.; Sarich, M.; Krahnert, W.-R.; Rossen, K.; Beller, M. Angew. Chem., Int. Ed. 2006, 45, 154-158. doi:10.1002/anie.200502697

33. Hamasaki, A.; Yasutake, Y.; Norio, T.; Ishida, T.; Akita, T.; Ohashi, H.; Yokoyama, T.; Honma, T.; Tokunaga, M. Appl. Catal., A 2014, 469, 146-152. doi:10.1016/j.apcata.2013.09.043

34. Hao, W.; Ding, G.; Cai, M. Catal. Commun. 2014, 51, 53-57. doi:10.1016/j.catcom.2014.03.027

35. Jiang, J.; Wang, P.; Cai, M. J. Chem. Res. 2014, 38, 218-222. doi: $10.3184 / 174751914 \times 13934116089943$

36. Eliseev, O. L.; Bondarenko, T. N.; Myshenkova, T. N.; Lapidus, A. L. Mendeleev Commun. 2014, 24, 229-230. doi:10.1016/j.mencom.2014.06.014

37. Chen, B.; Wu, X.-F. Org. Lett. 2019, 21, 2899-2902. doi:10.1021/acs.orglett.9b00930

38. Chien, C.-W.; Teng, Y.-H. G.; Honda, T.; Ojima, I. J. Org. Chem. 2018, 83, 11623-11644. doi:10.1021/acs.joc.8b01608

39. Dai, P.; Ogunlana, A. A.; Bao, X. J. Org. Chem. 2018, 83, 12734-12743. doi:10.1021/acs.joc.8b02178

40. Liu, Z.; Yang, Z.; Yu, B.; Yu, X.; Zhang, H.; Zhao, Y.; Yang, P.; Liu, Z. Org. Lett. 2018, 20, 5130-5134. doi:10.1021/acs.orglett.8b02027

41. Choi, G.; Hong, S. H. Angew. Chem. 2018, 130, 6274-6278. doi:10.1002/ange.201801524

42. Senthamarai, T.; Murugesan, K.; Schneidewind, J.; Kalevaru, N. V.; Baumann, W.; Neumann, H.; Kamer, P. C. J.; Beller, M.; Jagadeesh, R. V. Nat. Commun. 2018, 9, 4123. doi:10.1038/s41467-018-06416-6

43. Prichatz, C.; Trincado, M.; Tan, L.; Casas, F.; Kammer, A.; Junge, H.; Beller, M.; Grützmacher, H. ChemSusChem 2018, 11, 3092-3095. doi:10.1002/cssc.201801072

44. Ren, X.; Zheng, Z.; Zhang, L.; Wang, Z.; Xia, C.; Ding, K. Angew. Chem., Int. Ed. 2017, 56, 310-313. doi:10.1002/anie.201608628

45. Junge, K.; Wendt, B.; Cingolani, A.; Spannenberg, A.; Wei, Z.; Jiao, H.; Beller, M. Chem. - Eur. J. 2018, 24, 1046-1052. doi:10.1002/chem.201705201

46. Pedrajas, E.; Sorribes, I.; Guillamón, E.; Junge, K.; Beller, M.; Llusar, R. Chem. - Eur. J. 2017, 23, 13205-13212. doi:10.1002/chem.201702783 
47. Wang, L.; Neumann, H.; Beller, M. Angew. Chem., Int. Ed. 2018, 57, 6910-6914. doi:10.1002/anie.201802384

48. Dong, K.; Sang, R.; Liu, J.; Razzaq, R.; Franke, R.; Jackstell, R.; Beller, M. Angew. Chem., Int. Ed. 2017, 56, 6203-6207. doi:10.1002/anie.201701950

49. Liu, Z.; Yang, Z.; Ke, Z.; Yu, X.; Zhang, H.; Yu, B.; Zhao, Y.; Liu, Z. New J. Chem. 2018, 42, 13933-13937. doi:10.1039/c8nj03047b

50. Liu, Z.; Yang, Z.; Yu, X.; Zhang, H.; Yu, B.; Zhao, Y.; Liu, Z. Org. Lett. 2017, 19, 5228-5231. doi:10.1021/acs.orglett.7b02462

51. Liu, Z.; Yang, Z.; Yu, X.; Zhang, H.; Yu, B.; Zhao, Y.; Liu, Z. Adv. Synth. Catal. 2017, 359, 4278-4283. doi:10.1002/adsc.201701044

52. Liu, Z.; Yang, Z.; Wang, P.; Yu, X.; Wu, Y.; Wang, H.; Liu, Z. ACS Sustainable Chem. Eng. 2019, 7, 18236-18241. doi:10.1021/acssuschemeng.9b04803

53. Liu, Z.; Wang, P.; Ou, H.; Yan, Z.; Chen, S.; Tan, X.; Yu, D.; Zhao, X.; Mu, T. RSC Adv. 2020, 10, 7698-7707. doi:10.1039/c9ra10422d

54. Liu, Y.; Sun, Z.; Huang, C.; Tu, T. Chem. - Asian J. 2017, 12, 355-360. doi:10.1002/asia.201601537

55. Al-Shaal, M. G.; Wright, W. R. H.; Palkovits, R. Green Chem. 2012, 14, 1260-1263. doi:10.1039/c2gc16631c

56. Zhou, D.; Gao, Y.; Liu, B.; Tan, Q.; Xu, B. Org. Lett. 2017, 19, 4628-4631. doi:10.1021/acs.orglett.7b02254

57. Jessop, P. G.; Ikariya, T.; Noyori, R. Chem. Rev. 1995, 95, 259-272. doi:10.1021/cr00034a001

\section{License and Terms}

This is an Open Access article under the terms of the Creative Commons Attribution License (http://creativecommons.org/licenses/by/4.0). Please note that the reuse, redistribution and reproduction in particular requires that the authors and source are credited.

The license is subject to the Beilstein Journal of Organic Chemistry terms and conditions:

(https://www.beilstein-journals.org/bjoc)

The definitive version of this article is the electronic one which can be found at: $\underline{\text { doi:10.3762/bjoc. } 16.61}$ 